\title{
EVALUATION OF GENOTOXITY AND MUTAGENICITY OF DL-P-CHLOROPHENYLALANINE, ITS METHYL ESTER AND SOME N-ACYL DERIVATIVES
}

\author{
J. STRAUKAS* and LARISA CHAUSTOVA \\ Institute of Biochemistry, Moskslininku 12, Vilnius 2006, Lithuania
}

(Received: July 28, 1999; accepted: September 15, 1999)

\begin{abstract}
DL-p-chlorophenylalanine (PCPA) and its derivatives were evaluated for genotoxic effects using Escherichia coli and Bacillus subtilis strains lacking various DNA-repair mechanisms in spottest and in suspension test. The mutagenic activity of studied compounds was determined by the Ames test. Reverse mutation test was performed with Salmonella typhimurium strains TA98, TA100, TA1535 and TA1537 without S9 mix. 0.02 M nitrosomethylurea (NMU) standard mutagen was used as a positive control. The results showed that the parent nonessential amino acid PCPA had no detectable genotoxic and mutagenic activities in bacteria. The methyl ester of this amino acid and its N-phenylacetyl derivative possessed weak genotoxicity. Meanwhile N-sec-butyloxycarbonyl, N-benzyloxycarbonyl, N-(p-nitrophenylacetyl) and $\mathrm{N}$-(p-nitrophenoxyacetyl) derivatives of DL-p-chlorophenylalanine exhibited appreciable genotoxicity. Among the seven tested compounds only N-benzyloxycarbonyl and $\mathrm{N}$-(p-nitrophenoxyacetyl) derivatives of DL-p-chlorophenylalanine have been found to be mutagenic. Only parent PCPA possessed antimutagenic properties in respect of nitrosomethylurea. The structural modification, which strongly affects genotoxicity and mutagenicity perhaps may be due to steric hydrance of the substituents, causing interference with enzyme and DNA interactions.
\end{abstract}

Keywords: Genotoxicity - mutagenicity - DL-p-clorophenylalanine and its derivatives

\section{INTRODUCTION}

p-Chlorophenylalanine (PCPA, Fenclonine) is the long-lasting inhibitor of serotonin (5-hidroxytryptamine, 5-HT) synthesis. This nonessential amino acid blocks the ratelimiting enzyme tryptophan hydroxylase $[13,14]$. PCPA causes significant losses of dopamine, noradrenaline and adrenaline in most brain regions [24]. p-Chlorophenylalanine is a valuable experimental tool for study behaviour [20,23], memory $[10,25]$, sleep $[8,15]$, locomotion $[5,24]$ processes. PCPA specifically inactivated phenylalanine hydroxylase in hepatoma cells in culture $[21,22]$. The antineoplastic activity of p-chlorophenylalanine and some its derivatives was shown in experimental models $[1,7,11,27,29,30]$. In clinical investigation PCPA (Fenclonine) possessed positive effect against carcinoid syndrome [6, 28]. p-Chlorophenylalanine inhibited chemotherapy-induced emesis in cancer patients [3]. Thus, p-chloropheny-

*Corresponding author; E-mail: chaustov@bchi.lt 
lalanine and some of its derivatives are not only valuable tools in experimental investigations, but PCPA is also promising as a potential drug. In this paper we report the results of the study which was aimed at assessing the genotoxic properties of $p$ chlorophenylalanine, its methyl ester and some $\mathrm{N}$-acyl derivatives applying bacterial rec assay as a bacterial genetic toxicology test $[2,18]$ and mutagenic properties determined by Ames test $[12,19]$.

\section{MATERIAL AND METHODS}

\section{Agents}

DL-p-chlorophenylalanine hydrochloride (1), the sodium salts of N-sec-butyloxycarbonyl-DL-p-chlorophenylalanine (3), N-phenylacetyl-DL-p-chlorophenylalanine (4) and N-benzyloxycarbonyl-p-chlorophenylalanine (5) were synthesised according

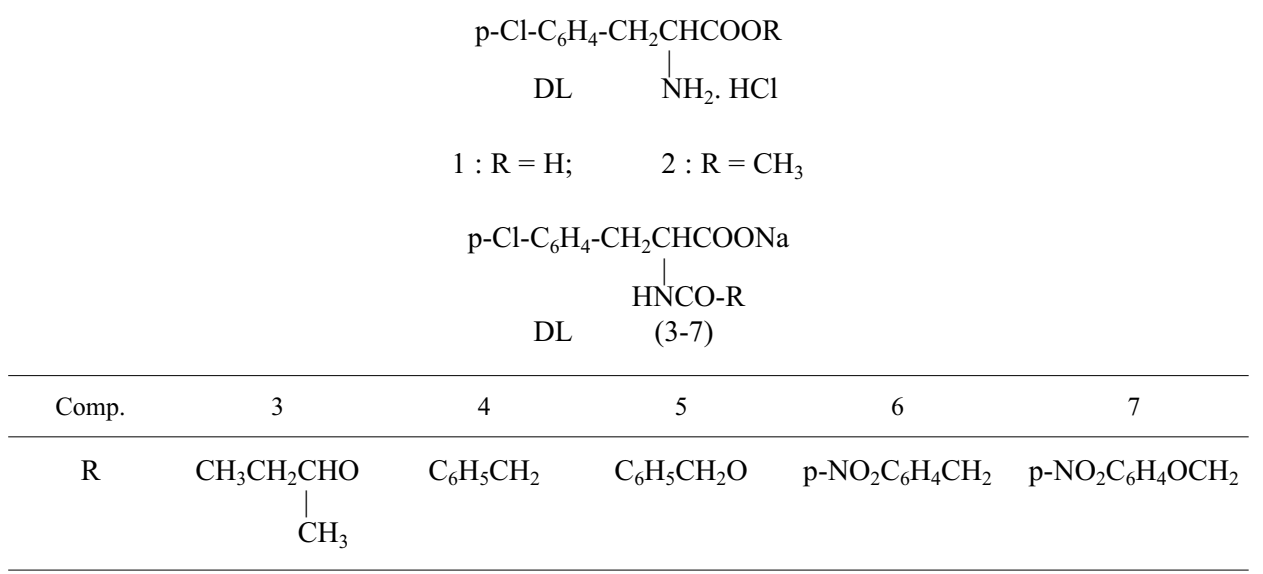

Fig. 1. Molecular structure of compounds (1-7) used in this study

to the procedure described earlier [29]. DL-p-chlorophenylalanine methyl ester hydrochloride (2) was prepared according to [9]. The sodium salts of N-(p-nitrophenylacetyl)-DL-p-chlorophenylalanine (6) and N-(p-nitrophenoxyacetyl)-DL-pchlorophenylalanine (7) were synthesised according a procedure described [30]. All tested compounds (1-7) are hydrosoluble. Molecular structures of DL-p-chlorophenylalanine derivatives (1-7) used in the present study are shown in Fig. 1. 


\section{Bacterial strains}

Escherichia coli $\mathrm{K}_{12} \mathrm{C} 5013$ as a wild strain, $\mathrm{JC} 7902$ ( $\mathrm{uvrA}^{-}$, $\mathrm{recA}^{-}$), $\mathrm{AB} 1886$ (uvrA6), AB2462 (recF), WP6 (polA1-), Bacillus subtilis BD170 $\left(\right.$ rec $\left.^{+}\right)$, BD190 (rec-), Salmonella typhimurium TA98, TA100, TA1535 and TA1537 strains were used in this study. All strains were kindly gifted from the Institute of High Molecular Compounds, Moscow, Russia.

\section{Growth medium}

Nutrient broth (NB, Difco) with $0.5 \% \mathrm{NaCl}$ added and LB (Difco) were used for bacterial cells growth. A solid medium contained 2\% agar (Difco) [17]. Cultures for tests were grown overnight at $37^{\circ} \mathrm{C}$ on a rotary shaker to the definite magnitude of optical density (OD).

\section{Genotoxicity assays}

Genotoxic properties of the tested compounds were determined using Escherichia coli and Bacillus subtilis strains lacking various DNA-repair mechanisms, when compared to the isogenic wild strain by spot test and by growing bacteria in liquid medium $[2,4,18]$. In our study bacteria overnight growing were concentrated at $5000 \mathrm{rpm}$ for $5 \mathrm{~min}$ and resuspended in potassium phosphate buffer $(0.1 \mathrm{M}$ $\left.\mathrm{Na}_{2} \mathrm{HPO}_{4} \cdot 7 \mathrm{H}_{2} \mathrm{O}, 0.1 \mathrm{M} \mathrm{NaH}_{2} \mathrm{HPO}_{4} \cdot \mathrm{H}_{2} \mathrm{O}, \mathrm{pH} 7,5\right)$ to $10^{8}$ cells $/ \mathrm{ml}$ when studied compounds were added. Cells were cultured at $37{ }^{\circ} \mathrm{C}$ with reciprocal shaking, and the growth was monitored by measuring the $\mathrm{A}_{590}$ periodically and number of the cells was compared with cells number in control wild strain suspension. Optical density was measured on photoelectrocolorimetr, using a green filter. All experiments were performed in triplicate.

\section{Mutagenic assay}

Mutagenic activity was determined using TA98, TA100, TA1535 and TA1537 Salmonella typhimurium strains according to the method described [12, 19]. This assay measures reverse mutations from histidine auxotrophy to prototrophy after exposure to varying dose levels of a test compound. $0.02 \mathrm{M}$ nitrosomethylurea (NMU) standard mutagen was used as positive control. All assay were conducted with 3 replicate plates.

\section{RESULTS}

In order to evaluate the genotoxic activity of the studied compounds we carried out our experiments with Escherichia coli and Bacillus subtilis strains lacking DNArepair mechanisms. Inhibition of bacterial growth was evaluated after $18 \mathrm{~h}$ at $37^{\circ} \mathrm{C}$. 
Table 1

Evaluation of genotoxicity of studied compounds with repair deficient system strains after $18 \mathrm{~h}$ of incubation by spottest

\begin{tabular}{cccc}
\hline \multirow{2}{*}{ Compounds } & \multicolumn{3}{c}{ Strains } \\
\cline { 2 - 4 } & \multicolumn{2}{c}{ Escherichia coli } & Bacillus subtilis \\
\cline { 2 - 4 } & AB2462 (uvrA6) & WP6 $\left(\mathrm{polA1}^{-}\right)$ & BD190 $\left(\mathrm{rec}^{-}\right)$ \\
\hline 1 & - & - & - \\
2 & - & - & \pm \\
3 & - & - & + \\
4 & - & \pm & + \\
5 & + & - & \pm \\
6 & + & \pm & + \\
\hline
\end{tabular}

Compounds were used in $2 \mathrm{mM}$ concentration.

$(-)$ - no genotoxic, $( \pm)$ - weakly genotoxic, $(+)$ - genotoxic

Table 2

Evaluation of genotoxicity of studied compounds after $18 \mathrm{~h}$ of incubation in the liquid medium

\begin{tabular}{|c|c|c|c|c|c|c|}
\hline \multirow{4}{*}{ Compounds } & \multicolumn{6}{|c|}{ Strains } \\
\hline & \multicolumn{4}{|c|}{ Escherichia coli } & \multicolumn{2}{|c|}{ Bacillus subtilis } \\
\hline & $\mathrm{K}_{12} \mathrm{C} 5013$ & JC7902 & AB2462 & WP6 & BD170 & BD190 \\
\hline & \multicolumn{6}{|c|}{ Optical density, \% } \\
\hline 1 & 82 & 80 & 105 & 105 & 144 & 110 \\
\hline 2 & 79 & 84 & 83 & 99 & 103 & 102 \\
\hline 3 & 98 & 10 & 94 & 100 & 10 & 10 \\
\hline 4 & 93 & 80 & 104 & 98 & 59 & 86 \\
\hline 5 & 100 & 82 & 38 & 98 & 12 & 11 \\
\hline 6 & 96 & 82 & 60 & 95 & 107 & 70 \\
\hline 7 & 113 & 87 & 75 & 97 & 69 & 100 \\
\hline Control & 100 & 100 & 100 & 100 & 100 & 100 \\
\hline
\end{tabular}

Compounds were used in $2 \mathrm{mM}$ concentration.

$\mathrm{P} \leq 0.05[16]$.

Results observed by spottest (Table 1) have shown that compound 1 did not show genotoxic activity in a DNA-repair test in bacteria. Compounds 2, 3 were not genotoxic in experiments with E. coli uvr and E. coli polA $A^{-}$strains, but have shown genotoxic effect in study with Bac. subtilis rec-. Compounds 4 and 6 have shown weak genotoxic effect against the polA $^{-}$strain and Bacillus subtilis rec ${ }^{-}$strain. Compound 4 was not genotoxic against $u v r$ strain, compound 5 did not show genotoxic effect against $E$. coli polA1 ${ }^{-}$strain. However, E. coli strain posses polA1 $^{-}$mutation was less 
sensitive to the treatment of tested compounds, except 7. On the other hand, among the repair-deficient strains, the Bac. subtilis rec ${ }^{-}$strain was far the most sensitive to the treatment in revealing the direct genotoxicity, especially to 3, 5 and 7 compounds (Table 1). Compound 5 was genotoxic against Bac. subtilis rec- strain as well as a $E$. coli uvr strain. Among the seven evaluated compounds, only 7 was genotoxic in all studies, and this compound completely inhibited bacterial growth after $18 \mathrm{~h}$. The viability of cells was not restored after subsequent incubation. Our results show that compounds 5-7 exhibited genotoxic activity relative to other compounds. Among seven compounds evaluated only compounds 3 and 5 exhibited the evident genotoxic effect when bacterial strains were grown in liquid medium supplemented with tested compounds (Table 2). The growth of bacteria was completely inhibited and the count of viable cells was not restored during the following incubation. Compounds 4, 6 and 7 exhibited moderate genotoxity. The genotoxic effect of the studied compounds was dose-related. The decrease of concentration from $0.02 \mathrm{mM}$ to $0.002 \mathrm{mM}$ revealed the distinctly expressed normalization of bacterial growth (data not shown).

Other experiments were carried out in order to determine the mutagenic properties of studied compounds. Results presented in Table 3 show that of seven evaluated compounds only compounds 5 and 7 were mutagenic since an increase in the number of revertants was observed with strain TA100 and TA1535, respectively. Furthermore, strain specificity indicated that the molecular mechanisms of tested compounds mutagenicity were affected by base substitution mutagens. Compounds $1-4$ and 6 were devoid of mutagenic activity. The absence of mutagenic activity was confirmed in at least 3 experiments. Only compound 1 possessed antimutagenic properties in respect of nitrosomethylurea (Table 3). Antimutagenic effect of $1 \mathrm{com}-$ pounds was dose-related, increase of the NMU concentration caused the decrease of antimutagenic effect (data not shown).

Table 3

Mutagenic activity of the studied compounds on the Salmonella thyphimurium strains

\begin{tabular}{|c|c|c|c|c|c|}
\hline \multirow{3}{*}{$\begin{array}{c}\text { Tested } \\
\text { compounds }\end{array}$} & \multicolumn{4}{|c|}{ Strains } & \multirow{3}{*}{$+0.02 \mathrm{M} \mathrm{NMU}$} \\
\hline & TA98 & TA100 & TA1535 & TA1537 & \\
\hline & \multicolumn{4}{|c|}{ Number of the his ${ }^{+}$revertants } & \\
\hline 1 & 57 & 90 & 45 & 16 & 60 \\
\hline 2 & 33 & 160 & 50 & 12 & 360 \\
\hline 3 & 43 & 110 & 52 & 20 & 400 \\
\hline 4 & 33 & 200 & 60 & 20 & 500 \\
\hline 5 & 68 & 245 & 50 & 40 & 460 \\
\hline 6 & 73 & 160 & 60 & 20 & 340 \\
\hline 7 & 40 & 100 & 95 & 10 & 320 \\
\hline Control & 53 & 100 & 40 & 22 & 280 \\
\hline
\end{tabular}

Values presented are the means of 3 replicates, $\mathrm{P} \leq 0.05[16]$.

All compounds were used in $1 \mathrm{mM}$ concentration 


\section{DISCUSSION}

Our results demonstrate, that DL-p-chlorophenylalanine hydrochloride 1 in a DNArepair test in bacteria, using 2 different techniques, did not exhibit genotoxicity and was devoid of mutagenic activity in the Ames reversion test. Meanwhile the methyl ester of this amino acid 2 was weakly genotoxic in spottest assay and was found to be non-mutagenic in the Ames test.

When DL-p-chlorophenylalanine was substituted at the $\mathrm{N}$ atom with sec-butyloxycarbonyl, benzyloxycarbonyl, p-nitrophenylacetyl or p-nitrophenoxyacetyl moieties, it was found that these compounds (3, 5, 6 and 7, respectively) possessed DNA damaging activity in the Bacillus subtilis rec assay. In the meanwhile, the introduction of the phenylacethyl moiety in the structure of this amino acid, the tested compound 4 exhibited only weak genotoxicity.

$\mathrm{N}$-Acylderivatives 5 and 7 were mutagenic, since an increase in number of revertants was observed with respect to the untreated cells. TA100 and TA1535 in the presence of the compounds 5 and 7 were found to be the most sensitive strains. Furthermore, strain specificity indicates that the molecular mechanisms of abovementioned compounds mutagenicity involve a base substitutions process. Only DLp-chlorophenylalanine hydrochloride 1 possessed from seven tested compounds antimutagenic properties in respect of nitrosomethylurea. Antimutagenic effect of PCPA was dose-related: the increase of the NMU concentration caused the decrease of antimutagenic effect.

\section{CONCLUSION}

Our findings demonstrate that PCPA is devoid genotoxic and mutagenic properties and has an antimutagenic effect that is favourable for use of this nonproteinogenic amino acid in clinical practice. Meanwhile the modification of the structure of PCPA led to compounds that significantly differed from genotoxic and mutagenic properties of parent amino acid. Such change of properties, may be due to the steric hindrance of the substituents, which interferes with enzyme and DNA interactions.

\section{REFERENCES}

1. Baguley, B. C., Cole, G., Thomsen, L. L., Li Z. (1993) Serotonin involvement in the antitumour and host effects of flavone-8-acetic acid and 5,6-dimethylxanthenone-4-acetic acid. Cancer Chemother. Pharmacol. 33, 77-81.

2. Benvenuti, S., Severi, F., Sacchetti, A., Melegari, M., Vampa G. (1997) Synthesis, antimicrobial and genetoxic properties of some benzoimidazole derivatives. Il Farmaco 52, 231-235.

3. Cubeddu, L. X. (1996) Serotonin mechanisms in chemotherapy-induced emesis in cancer patients. Oncology 53, Suppl. 1 18-25.

4. De Flora, S., De Renzi, G. P., Camoirano, A., Astengo, M., Basso, C., Zanacchi, P., Bennicelli, C. (1985) Genotoxicity assay of oil dispersants in bacteria (mutation, differential lethality, SOS DNArepair) and yeast (mitotic crossing-over). Mutation Res. 158, 19-30. 
5. Dringenberg, H. C., Hargreaves, E. L., Baker, G. B., Cooley, R. K., Vanderwolf, C. H. (1995) pChlorophenylalanine-induced serotonin depletion: reduction in exploratory locomotion but no obvious sensory-motor deficits. Behav. Brain Res. 68, 229-237.

6. Engelman, K., Lovenberg, W., Sjoerdsma, A. (1967) Inhibition of serotonin synthesis by parachlorophenylalanine in patients with the carcinoid syndrome. N. Engl. J. Med., 277, 1103-1108.

7. Hodson, C. A., Simpkins, J. W., Meites, J. (1978) Effect of brain serotonin reduction on growth of carcinogen-induced mammary tumors in rats. IRCS Med. Sci. 6, 398.

8. Huitron-Resendiz, S., Rios, C., Rojas, P., Mexicano, G., Ayala-Guerrero, F. (1997) Effect of pchlorophenylalanine (PCPA) on sleep and monoamines content in the brain of a lizard species. Brain Res. 761, 19-24.

9. Iselin, B. M., Huang, H. T., MacAllister, R. V., Niemann, C. (1950) A new series of substrates for the evaluation of chymotrypsin activity. J. Am. Chem. Soc. 72, 1729-1731.

10. Jakala, P., Sirvio, J., Riekkinen, Jr., Riekkinen, P. J. Sr. (1993) Effects of p-chlorophenylalanine and methylsergide on the performance of a working memory task. Pharmacol. Biochem. Behav. 44, 411-418.

11. Kelly, C. J., Johnson, T. C. (1978) Effects of p-chlorophenylalanine and $\alpha$-methylphenylalanine on amino acid uptake and protein synthesis in mouse neuroblastoma cells. Biochem. J. 174, 931-938.

12. Killbey, B. J., Legator, M., Nichols, W., Ramel, C. (1984) Handbook of mutagenicity. Test procedures, Amsterdam-New York-Oxford, 1-13.

13. Koe, B. K. (1971) Trytophan hydroxylase inhibitors. Fed. Proc. 30, 886-896.

14. Koe, B. K., Weissman, A. (1966) p-Chlorophenylalanine: a specific depletor of brain serotonin. $J$. Pharmacol. Exp. Ther. 154, 499-516.

15. Li, H., Sattinoff, E. (1992) Effects of p-chlorophenylalanine on thermoregulation and sleep in rats. Brain Res. 569, 46-56.

16. Litchfield, J. T., Wilcoxon, F. (1949) A simplified method of evaluating dose-effects experiments. Pharmacol. Exp. Ther. 96, 99-113.

17. Maniatis, T., Fritsch, E. F., Sambrook, J. (1982) Molecular cloning: A laboratory manual. Cold Spring Harbor, N. Y.

18. Mamber, S. W., Bryson, V., Katz, S. E. (1983) The Escherichia coli WP2/WP100 rec assay for detection of potential chemical carcinogens. Mutation Res. 119, 135-144.

19. Maron, D. M., Ames, B. N. (1983) Revised methods for the Salmonella mutagenicity test. Mutation Res. 113, 173-215.

20. Matsumoto, T., Yamanouchi, K. (1997) Effects of p-chlorophenylalanine on male sexual behaviour in female rats with mesencephalic raphe nuclei lesions. Endocr. J. 44, 383-388.

21. Miller, D., McClure, R., Shiman, R. (1975) p-Chlorophenylanine effect on phenylalanine hydroxylase in hepatoma cells in culture. J. Biol. Chem. 250, 1132-1140.

22. Miller, D., McClure, R., Shiman, R. (1976) Mechanism of inactivation of phenylalanine hydroxylase by p-chlorophenylalanine in hepatoma cells in culture. J. Biol. Chem. 251, 3677-3684.

23. Motles, E., Gomez, A., Briones, C., Gonzales, M. (1991) Effects of p-chlorophenylalanine on the behaviours induced by apomorphine and amphetamine in adult cats. Prog. Neuropsychopharmacol. Biol. Psychiatry 15, 105-117.

24. Myoga, S., Nonaka, K., Matsuyama, S., Mori (1995) Postnatal development of locomotor movements in normal and para-chlorophenylalanine-treated new born rats. Neurosci. Res. 21, 211-221.

25. Petkov, V. D., Belcheva, S., Konstantinova, E., Kehayov, R. (1995) Participation of different 5-HT receptors in the memory process in rats and its modulation by the serotonin depletor p-chlorophenylalanine. Acta Neurobiol. Exp. (Warszawa) 55, 243-252.

26. Reader, T. A. (1989) Neurotoxins that affect central idoleamine neurons. In: Boulton, A. A., Baker, G. B., Juorio, A. V. (eds). Drugs as Tools in Neurotransmitter Reseach, Humana Press, Clifton, N. J., 49-102.

27. Siegal, T. (1993) Serotonergic manipulations in experimental neoplastic spinal cord compression. $J$. Neurosurg. 78, 929-937.

28. Sjoerdsma, A. (1971) Clinical implication of unnatural amino acids and amines. Fed. Proc. 30, 908-911. 
29. Straukas, J., Kersulis, A. (1974) Synthesis and antitumour activity of some N-acyl derivatives of DLp-chlorophenylalanine. Khim.-Farm. Zh., 1116-1119 (In Russian).

30. Straukas, J., Kersulis, A., Simkeviciene, V. (1979) Synthesis and antitumour activity of some N-arylacetyl and N-aryloxyacetyl derivatives of aromatic amino acids, in: Kanopkaite, S. (ed.), Metabolism and Its Regulation by Biologically Active Compounds, Institute of Biochemistry, Vilnius, 96-101 (In Russian).

31. Vinnitsky, V. B., Yakimenko, V. A. (1981) The effect of phenformin, L-DOPA and parachlorophenylalanine treatment on immune response and chemical carcinogenesis development in BALB/c mice. Vopr. Onkol., 27, 45-50. (In Russian) 